\title{
POLÍTICAS URBANAS, CONFLITOS SOCIAIS \\ E DIREITO DE PROPRIEDADE NO BRASIL DA VIRADA DO SÉCULO XX
}

Pedro Jimenez Cantisano

\section{INTRODUÇÃO}

Este artigo apresenta duas histórias que se entrecruzaram tanto no início do século XX, quando um plano de reformas urbanas segregou a cidade do Rio de Janeiro, quanto no final do mesmo século, nas lutas das comunidades cariocas pelo direito à cidade. A primeira história aborda o impacto das reformas urbanas, que contribuíram de maneira singular para a expansão das favelas cariocas, no desenvolvimento do conceito de "função social da propriedade" na doutrina jurídica brasileira. A segunda história mostra que, durante as reformas do Rio de Janeiro, os moradores de cortiços se apropriaram do conceito jurídico da inviolabilidade da "casa", "lar" ou "domicílio" para resistir aos despejos e invasões domiciliares. Este artigo também levanta a hipótese de que, durante o século XX, as lutas pelo direito à cidade mantiveram seu formato estratégico, mas passaram por uma transição conceitual. No final do século, o conceito relevante era o de propriedade, mais especificamente, o da "função social da propriedade", articulado em conjunto com reivindicaçôes pelo direito à moradia. Ambas as histórias e suas interseçôes necessitam de pesquisas mais aprofundadas. Neste artigo, limito-me à utilização de processos judiciais, jornais, documentos administrativos e doutrina jurídica da primeira década do século XX, combinados com a produção bibliográfica de historiadores, juristas e cientistas sociais sobre o que ocorreu nas décadas posteriores.

Apesar destas limitações, os pontos de interseção entre as duas narrativas e a hipótese levantada indicam que as histórias da intervenção estatal no meio urbano, 
das lutas sociais pelo acesso à cidade e do conceito jurídico de propriedade, até o momento separadas por fronteiras historiográficas, devem ser entendidas em conjunto. ${ }^{11}$ Durante todo o século XIX, as elites técnicas e políticas brasileiras desenvolveram ideias sobre o poder de polícia, a higiene e o urbanismo, que culminaram com a rigorosa intervenção estatal no direito de propriedade, através de numerosas desapropriações e interdições de prédios por motivos de higiene e alinhamento de ruas, no início do século XX. Naquele momento, a mobilização social nos tribunais, nos jornais e nas ruas mostrou-se contrária à intervenção do Estado. Ainda que separados socialmente, os pequenos proprietários e seus inquilinos fizeram parte de um movimento de resistência baseado em liberdades individuais: para aqueles, a propriedade, para estes, a inviolabilidade de domicílio. Apesar da resistência, as políticas urbanas que haviam se desenvolvido durante o século anterior contribuíram para a modificação doutrinária do conceito de propriedade. Ao lado de influências intelectuais europeias, estas políticas foram fundamentais para a consolidação do conceito de propriedade limitada pelo bem comum, pela necessidade social ou, como conhecemos hoje, pela função social. Ironicamente, o novo conceito de propriedade, resultante, entre outros fatores, das políticas que segregaram a cidade, seria, mais tarde, apropriado pelas comunidades formadas pelas pessoas que haviam sido removidas dos cortiços do centro, em suas lutas contra remoções. Esta história política, social e intelectual da propriedade nos lembra que políticas públicas, lutas sociais e doutrina jurídica não podem ser consideradas isoladamente.

\section{AS REFORMAS URBANAS DO INÍCIO DO SÉCULO XX}

Entre 1903 e 1909, a cidade do Rio de Janeiro, então capital da República, passou por transformações radicais. O Presidente Rodrigues Alves, representante das oligarquias cafeicultoras paulistas, promoveu um plano de modernização urbana

\footnotetext{
A historiografia sobre a cidade nos séculos XVIII e XIX dedicou-se, principalmente, aos ideais de cidade pretendidos pelas elites e aos meios utilizados para implementá-los (SCHULTZ, 2001; CARVALHO, 2008). Entre estes meios, encontrava-se uma versão instrumental da doutrina jurídica do poder de polícia, reformulada pelos juristas franceses e portugueses após a queda do Antigo Regime (SEELAENDER, 2008). A historiografia sobre as reformas urbanas do início do século XX enfatizou as lutas sociais contra o processo de segregação que se intensificava, sem, no entanto, discutir as ideias jurídicas com profundidade (BENCHIMOL, 1992; CARVALHO, 1995). Finalmente, a historiografia sobre o direito de propriedade se divide em (1) história social da propriedade rural e escrava (MOTA, 1998; GRINBERG, 2002) e (2) análises focadas na história política e intelectual do direito de propriedade (VARELA, 2005).
} 
com o objetivo de impulsionar o papel do Brasil como nação agroexportadora na economia mundial. Alves nomeou engenheiros, como o Prefeito Pereira Passos, e médicos, como o Diretor Geral de Saúde Pública Oswaldo Cruz, para comandar os planos de reformulação, embelezamento e saneamento da cidade, que deveriam torná-la atraente a imigrantes e investimentos estrangeiros (BENCHIMOL, 1992). Estes administradores técnicos, que vinham ganhando espaço na política desde meados do século XIX, ainda sob o governo imperial, lideraram a tentativa de transformação do Rio de Janeiro colonial em uma metrópole bela, eficiente e higiênica, inspiradas na Paris reformada pelo Barão de Haussmann, entre 1853 e 1870 - modelo de progresso civilizatório para as elites brasileiras.

Desapropriaçõos e demolições de prédios antigos e cortiços, considerados anti-higiênicos, abriram espaço para a construção de avenidas largas, como a Avenida Central (atual Rio Branco) e praças, projetadas para facilitar o fluxo de mercadorias em direção ao porto, embelezar a cidade e conter a transmissão de doenças. Os governos federal e municipal contraíram empréstimos consideráveis e realizaram concessōes para a construção de uma nova infraestrutura, incluindo o novo porto, os bondes e os sistemas de iluminação e esgoto. Arquitetos foram contratados para projetar as fachadas dos novos edifícios, modelados por um estilo arquitetônico eclético, como, por exemplo, o Theatro Municipal, inspirado na Opéra de Paris.

Contra as desapropriações, tanto os proprietários tradicionais, como as ordens religiosas - que haviam sido fundamentais no processo de urbanização desde o século XVI - e os produtores rurais que investiram no solo urbano, quanto os que haviam acumulado capital recentemente, como os imigrantes europeus que controlavam o mercado de moradia, se uniram para defender a sacralidade do direito de propriedade. Apoiados por políticos de oposição, os proprietários formaram associaçõos e contrataram advogados para mobilizar os tribunais e a imprensa contra as ameaças ao seu domínio econômico e político garantido pela propriedade.

Ainda que alguns reformadores apresentassem as reformas como medidas progressistas destinadas a melhorar as condições de vida dos mais pobres, o plano implementado no Rio de Janeiro era parte de uma campanha das elites governantes pela limpeza social, moral e, implicitamente, racial da cidade. Despejados de suas residências, os trabalhadores, em sua maioria negros, se mudaram para os subúrbios, onde o acesso ao trabalho era difícil, ou ocuparam os morros próximos ao centro, abrindo mão de segurança e higiene para permanecerem próximos às oportunidades de trabalho. Na medida em que a disponibilidade de moradia barata no 
centro declinava e os aluguéis aumentavam, a modernização aprofundou a crise habitacional e a segregação espacial do Rio de Janeiro. O projeto de reformas foi acompanhado pelo recrudescimento do controle social, realizado pela polícia, sobre as chamadas "classes perigosas" e sobre manifestaçôes culturais e estratégias de sobrevivência dos mais pobres, como o carnaval e o comércio de rua. Os agentes sanitários, comandados por Oswaldo Cruz, frequentemente invadiam residências para realizar expurgos e vacinar forçosamente a população, ordenavam o fechamento de cortiços, multavam e pediam a prisão de proprietários e inquilinos (BENCHIMOL, 1992).

Os trabalhadores da cidade resistiram, trancando suas portas, indo ao judiciário, escrevendo para a imprensa e tomando as ruas, durante o episódio de novembro de 1904, conhecido como Revolta da Vacina. Nos tribunais, na imprensa e nas ruas, a mobilização dos inquilinos, às vezes em surpreendentes alianças com proprietários, baseou-se no direito constitucional à inviolabilidade de domicílio. Incapazes de reivindicar qualquer direito à propriedade de suas moradias, os pobres encontraram na ideia de que casa era um "asilo inviolável" o fundamento para uma consciência de direitos, impulsionada por decisões judiciais e pela cobertura midiática, contra as invasões e despejos ordenados pelos agentes sanitários (CARVALHO, 2011; CANTISANO, 2015).

\section{COMO A CIDADE MUDOU O DIREITO DE PROPRIEDADE}

Em março de 1906, a Associação em Defesa da Propriedade publicou seu manifesto inaugural intitulado "Propriedade Individual". O manifesto mostrava a preocupação dos proprietários da capital com o impacto das "tendências ultra-coletivistas" do governo no direito de propriedade. De acordo com os membros da Associação, o direito garantido pelo artigo $72, \$ 17$, da Constituição de 1891 , havia se tornado ficção no Distrito Federal. Uma nova concepção de poderes públicos, implícita na legislação recém-aprovada, apontava para uma desconfiança em relação ao poder judiciário, que seria incumbido de proteger os indivíduos contra o "socialismo". As evidências estavam na arquitetura jurídica criada para facilitar as reformas urbanas, que incluía os novos, excepcionais e violentos procedimentos para desapropriaçóes. ${ }^{12}$

Nos casos de desapropriação que chegavam ao judiciário, os proprietários da capital e seus advogados apelavam para a sacralidade do direito de propriedade.

12 Propriedade Individual. Jornal do Brasil, 9 de março de 1906. 
Defendiam um conceito individualista e absoluto de propriedade para proteger seu patrimônio contra o ímpeto reformador do Estado. Entretanto, no início do século XX, o direito de propriedade no Brasil já apresentava traços de uma transição direcionada a uma nova ideia de propriedade, cada vez mais limitada pelo que as autoridades entendiam ser o bem, a utilidade e a necessidade públicos. Dos dois lados do debate, proprietários, advogados, juízes, administradores públicos e doutrinadores apropriavam ideias, como "individualismo", "coletivismo" e "socialismo", a fim de protegerem seus interesses financeiros, profissionais, políticos e intelectuais. Concepções conflitantes de propriedade apareceram em disputas pela cidade, assim como em debates intelectuais sobre os fundamentos filosóficos do direito e do Estado, deixando, portanto, o futuro do direito de propriedade brasileiro em aberto.

Em meados do século XIX, durante o período imperial (1822-1889), o direito de propriedade havia passado por sua primeira transformação. Como parte do esforço para modernizar o direito e a economia brasileiros, o imperador Dom Pedro II, o Conselho de Estado e o Parlamento promoveram a substituição do sistema colonial de sesmarias. As sesmarias, uma forma medieval de acesso à terra, haviam sido concedidas de maneira precária e condicional pela coroa portuguesa como estratégia de colonização, desde o século XVI. Caso o sesmeiro não cultivasse sua terra e, portanto, deixasse de pagar os impostos que drenavam a riqueza da colônia para a metrópole, o rei tinha a prerrogativa de revogar a sesmaria concedida. Com a independência, em 1822, a concessão de sesmarias foi suspensa. Entre 1822 e meados do século XIX, o acesso à terra no Brasil se baseou exclusivamente na posse. Durante este período, pequenos e grandes produtores rurais expandiram sua posse pelo solo brasileiro, entrando em conflitos constantes (MOTTA, 1998). A Lei de Terras, de 1850, seguida pela Lei Hipotecária, de 1864, marcou o início da transição para o sistema moderno de propriedade individual, absoluta e distribuída via mercado. Esta transição teve como objetivo dar segurança jurídica aos proprietários. No entanto, o acesso à terra não foi democratizado. $\mathrm{Na}$ medida em que o título se tornou elemento fundamental da propriedade, as terras brasileiras se concentraram cada vez mais nas mãos de grandes proprietários, politicamente capazes de mobilizar o aparato jurídico para legitimar suas posses com títulos forjados e financeiramente capazes de comprar novos títulos de propriedade. Ainda que a posse e a ocupação de terras jamais tenham cessado no país, na legislação e na doutrina jurídica, a propriedade era definida a partir dos parâmetros do sistema moderno (VARELA, 2005). 
Em um país predominantemente rural e dependente da exportação de produtos primários, os debates políticos que moldaram esse processo de modernização foram determinados pelo acesso à terra e à propriedade escrava. Após a proibição do tráfico, em 1831, a disponibilidade de escravos estava em decadência e, portanto, a terra se consolidava como o principal bem econômico dos proprietários. Mesmo assim, a modernização também afetou a propriedade escrava. A Lei do Ventre Livre, de 1871, além de tornar livres todos os nascidos de mãe escrava, determinou a matrícula de todos os escravos existentes no Império, que foi executada no ano seguinte. A lei, portanto, contribuiu para a legalização de escravos em situação ambígua, como aqueles que haviam sido traficados para o Brasil após a proibição de 1831, e para o registro da propriedade escrava, criando, portanto, segurança jurídica para os senhores (MAMIGONIAN, 2011). Com base neste cenário, os historiadores do direito de propriedade no Brasil deram atenção quase exclusiva às propriedades rural e escrava.

Entretanto, o século XIX também foi um momento de transformações na propriedade urbana. Desde 1808, quando a família real portuguesa transferiu a capital do seu império para o Rio de Janeiro, fugindo da invasão napoleônica à Península Ibérica, a propriedade urbana sofreu crescentes limitações. Apesar da resistência dos proprietários, que invocavam a "sacralidade" do direito de propriedade, a coroa utilizou o instrumento das aposentadorias para requisitar propriedades, especialmente sobrados, considerados mais higiênicos e confortáveis, para acomodar os membros da corte que se refugiaram no Brasil. Para reformular a nova capital, transformando a cidade colonial em uma "Versailles Tropical", o rei Dom João VI criou a décima, imposto de $10 \%$ sobre a propriedade urbana, e a Intendência Geral de Polícia, instituição moldada na intendência criada pelo Marquês de Pombal para coordenar a reconstrução de Lisboa após o terremoto de 1755. No império português, as intendências exerciam o poder de polícia, entendido pelos juristas portugueses como a prerrogativa do rei de transformar a realidade social e econômica para maximizar o poder do Estado através do crescimento econômico e populacional e da colonização (SEELAENDER, 2008). No Rio de Janeiro, a Intendência foi encarregada de promover o "bem comum" através de obras públicas, como a construção de sistemas de abastecimento de água e iluminação, e da disciplina moral e social, como no combate ao crime a à dissidência política e no controle da comercialização de escravos. O crescimento populacional e a requisição de propriedade para os nobres geraram a primeira crise habitacional da cidade. A In- 
tendência, então, criou isenções à décima para estimular construções na área de Cidade Nova, até então ocupada por pântanos. Todas estas interferências criaram restrições aos direitos dos proprietários da cidade, gerando conflitos que se estenderiam até depois da independência (SCHULTZ, 2001; CARVALHO, 2008).

As intervenções no espaço urbano do Rio de Janeiro e as consequentes limitações ao direito de propriedade continuaram após 1822. Na década de 1830, a monarquia e as câmaras municipais consolidaram regras para o uso do solo urbano nos códigos de posturas. O Código do Rio de Janeiro determinava, por exemplo, que os proprietários eram obrigados a zelar pela integridade de bens públicos, como o pavimento das calçadas e os sistemas de abastecimento de água. Eles também deveriam pagar pela demolição de seus prédios, quando estes fossem condenados por estarem "em ruínas". ${ }^{13} \mathrm{Na}$ década de 1850, com a emergência da ideologia da higiene, surgiram as primeiras propostas para controlar os usos das habitaçóes coletivas, crescentemente associadas à criminalidade, a condutas imorais e à falta de higiene, bem como às epidemias de febre amarela e varíola que assolavam a capital. Em 1853, por exemplo, o secretário de polícia propôs que os donos de cortiços apresentassem uma lista de moradores para fins de controle. Em 1855, a Câmara Municipal determinou que a construção de novos cortiços dependeria de uma licença municipal e de aprovação da Junta de Hygiene (CHALHOUB, 1996, p. 32).

$\mathrm{Na}$ década de 1870, mais uma vez reagindo a epidemias, o governo criou a Comissão para Melhoramentos da Cidade do Rio de Janeiro, liderada pelo engenheiro Pereira Passos, recém-chegado de Paris, onde havia observado as grandes reformas urbanas do Barão de Haussmann. Em seu primeiro relatório, a Comissão propôs obras de expansão e melhoramento da malha urbana carioca em regiões periféricas, como as zonas norte e sul. Parte da justificativa para este foco se baseava na preservação das propriedades mais importantes e valiosas do centro da cidade. No segundo relatório, no entanto, a Comissão propôs o primeiro grande plano de reformulação do centro. Todas as propostas envolviam desapropriações e outras limitações ao direito de propriedade. Entretanto, a Comissão se mostrou fraca, com pouco apoio político e recursos para implementar seu plano. Dom Pedro II não estava disposto a gastar dinheiro público com reformas urbanas e a iniciativa privada não atendeu às chamadas da Comissão (FURTADO, 2003). As intervenções

13 Posturas da Câmara do Rio de Janeiro, de 4 de outubro de 1830. In: Colleção das Decisóes do Governo do Imperio do Brasil. Rio de Janeiro: Typographia Nacional, 1875. 


\section{•• Série Direito, Economia e Sociedade}

pontuais para saneamento da capital, por outro lado, se fortaleceram. Na década de 1880, o ataque aos cortiços da cidade foi intensificado depois que o governo ordenou, em dezembro de 1879, a condenação de todos os cortiços considerados "em ruínas" e ameaças à saúde pública (CHALHOUB, 1996, p. 45).

De acordo com o historiador Sidney Chalhoub, entre outros fatores, o "pacto liberal de defesa da propriedade privada" teria impedido as autoridades imperiais de implementar planos urbanos abrangentes (CHALHOUB, 1996, p. 45). Este pacto certamente existiu entre os membros da elite proprietária da época, que controlavam todas as instâncias de governo. Porém, os juristas da segunda metade do século XIX já admitiam que a propriedade privada sofria limitações. Na Consolidação das Leis Civis de 1876, Teixeira de Freitas, encarregado pelo governo imperial de redigir o primeiro código civil brasileiro, apresentou a propriedade como um direito absoluto. No entanto, Freitas também indicou que "as restrições que harmonizam [o direito de propriedade] com as exigências do bem social" pertenciam às "Leis de Polícia". A Consolidação incluía uma seção regulando as desapropriações por utilidade e necessidade pública com base na Constituição do Império, de 1824 , e em decretos imperiais, como o decreto de 1855 , que havia criado procedimentos sumários de desapropriação para facilitar a construção de ferrovias (FREITAS, 1876, p. cvi). A separação artificial entre direito privado, da Consolidação, e direito público, representado pelas "Leis de Polícia", permitiu que Freitas mantivesse a propriedade como um direito absoluto apesar das inúmeras limitações que haviam sido criadas durante o século XIX.

Freitas, portanto, justificou as limitações à propriedade sem, no entanto, modificar o conceito de propriedade que predominava no processo de modernização inaugurado pela Lei de Terras, de 1850. Porém, a partir do final do século XIX, a intervenção estatal no direito de propriedade para fins de controle higienista se intensificou. Em 1893, no início da República, o Prefeito Barata Ribeiro comandou a demolição do cortiço Cabeça de Porco, inaugurando um modelo violento de remoção dos trabalhadores das áreas centrais do Rio de Janeiro. No início do século XX, as oligarquias rurais dominantes, representadas pelo Presidente Rodrigues Alves, assim como as elites profissionais de médicos e engenheiros que haviam conquistado espaço no governo, representadas pelo, agora, Prefeito Pereira Passos e pelo Diretor Geral de Saúde Pública, Oswaldo Cruz, uniram forças para reformar a capital. A arquitetura legislativa produzida por esta coalizão impôs limites ainda maiores ao direito de propriedade. $\mathrm{O}$ decreto de 1855 para construção de ferrovias 
foi estendido à cidade, com algumas modificações. Agora, quando não houvesse acordo entre a municipalidade e os proprietários, ao invés de um júri composto por proprietários locais, três árbitros, escolhidos entre engenheiros e higienistas, determinariam os valores das indenizações. ${ }^{14} \mathrm{~A}$ base de cálculo das indenizações foi reduzida de 20 para 10 vezes o valor locativo. ${ }^{15}$ Se as autoridades municipais considerassem o prédio em estado de "ruínas", poderiam determinar indenizações abaixo do mínimo legal. ${ }^{16}$ Os tribunais foram proibidos de conceder interditos possessórios contra atos do prefeito e do diretor geral exercidos ratione imperii, uma expressão que gerou conflitos interpretativos intensos nos jornais, na doutrina e nos tribunais durante as reformas urbanas (CANTISANO, 2016). ${ }^{17}$ Finalmente, o Código Sanitário de 1904, que ganhou o apelido de "Código de Torturas", impunha inúmeras obrigações aos proprietários, sujeitando-os à condenação e fechamento de suas propriedades e a penas de multa e até prisão. ${ }^{18}$

Os procuradores municipais e da saúde pública defenderam as intervenções para fins de embelezamento e saneamento urbano com base em concepções expandidas dos conceitos de interesse, utilidade, necessidade e bem comum, público ou coletivo. José de Miranda Valverde, procurador dos feitos da fazenda municipal, por exemplo, defendeu a desapropriação por zonas, em 1906, argumentando que a complexidade da sociedade moderna demandava um conceito mais abrangente de utilidade pública. Este tipo de desapropriação, estratégia que Passos importara da França, consistia em desapropriar mais do que o necessário para, então, vender as sobras a fim de financiar os projetos de abertura e alargamento de ruas e avenidas. Procuradores da saúde pública, como Primitivo Moacyr, acusavam os proprietários de cortiços de serem gananciosos exploradores das classes mais pobres, homens que colocavam seus interesses privados no lucro acima da saúde pública, ou seja, do bem comum. Quando Pereira Passos ordenou a desapropriação dos prédios vazios, de propriedade de estrangeiros que, segundo ele, eram meros especuladores, o prefeito declarou estar usando um "recurso legítimo de defesa dos interesses da coletividade contra os abusos de um certo número de proprietários”. ${ }^{19}$

\footnotetext{
14 Decreto 4956, de 9 de setembro de 1903, 21, $\$ 1^{\text {o }}$.

15 Decreto 4956, de 9 de setembro de 1903, art. 31, $₫ 5^{\circ}$.

16 Decreto 4956, de 9 de setembro de 1903, art. 31, $\$ 9^{\circ}$.

17 Lei 939, de 29 de dezembro de 1902, art. 16; Decreto 1.151, de 5 de janeiro de 1904, art. 1º, $\$ 20$.

18 Decreto 5156, de 8 de março de 1904.

19 Mensagem do Prefeito ao Conselho Municipal, 4 de abril de 1905, p. 79.
} 
Portanto, os reformadores não defendiam uma mudança radical no conceito de propriedade, mas apenas a expansão dos limites externos a este direito. Do outro lado, quando se defendiam contra as desapropriações nos tribunais, os proprietários e seus advogados argumentavam que aqueles limites externos, baseados em interesses coletivos, haviam inflado ao ponto de se tornarem ameaças à ideia de propriedade individual e absoluta. Defendendo seu cliente no processo de desapropriação dos prédios localizados na rua Frei Caneca, números 178 e 180, o advogado Pedro Travares Jr. resumiu este argumento afirmando que a nova legislação "atinge o direito de propriedade na sua essência”. ${ }^{20}$

Assim como a Associação em Defesa da Propriedade, em seu manifesto, alguns advogados e até um juiz, nos tribunais, levaram este argumento ao extremo, equiparando a administração do Distrito Federal a um regime socialista. Em 1905, na desapropriação judicial do prédio na rua do Ouvidor, número 141, de propriedade de uma família estrangeira, o advogado afirmou que a tentativa de desapropriação era um confisco, "no sentido vermelho e jacobino" do termo. ${ }^{21}$ Em 1908, em um voto minoritário, o juiz Montenegro, da Corte de Apelação, citou um artigo publicado por Lafayette Rodrigues Pereira, em 1905. De acordo com Montenegro, Pereira teria argumentado que os níveis de interferência no direito de propriedade na capital eram comparáveis aos de um "Estado socialista". A municipalidade teria reduzido os indivíduos a "pupilos" do Estado e a propriedade seria inteiramente administrada pelo governo. A Constituição de 1891 protegia o direito de propriedade em toda sua plenitude e, portanto, não autorizava este sistema "socialista", apesar da previsão de desapropriações por interesse e necessidade públicos. ${ }^{22}$

No início do século XX, havia diversas organizações que se identificavam como socialistas no Rio de Janeiro. Em 1902, por exemplo, fora fundado o Centro das Classes Operárias, uma organização socialista que reunia vários sindicatos. $\mathrm{O}$ Centro teve participação ativa na Revolta da Vacina, em novembro de 1904, quando organizou a oposição à vacinação obrigatória em petições ao congresso e reuniōes em sua sede, no Largo do São Francisco, onde as manifestações tiveram início (MEADE, 1998, p. 98). Este cenário de intensa mobilização política pode ter

20 Arquivo Nacional, Fundo: Juízo dos Feitos da Fazenda Municipal, João Leopoldo Modesto Leal, 1905, 54, caixa 619.

21 Arquivo Nacional, Fundo: Juízo dos Feitos da Fazenda Municipal, Fernanda Maria Pilar Bregaro, 1905, 33, caixa 618 .

22 Apelação crime 509, publicada em $O$ Direito 107, 1908, 322-324. 
influenciado os juristas que se apropriaram do termo "socialismo" para criticar as reformas urbanas. No entanto, nem os interesses e objetivos explícitos e implícitos dos reformadores, nem a ideia de socialismo adotada pelas organizações operárias se adequavam ao que os juristas chamavam de socialismo.

Em primeiro lugar, as reformas urbanas tinham como objetivo reforçar o papel do Brasil na economia capitalista mundial. Os alargamentos e aberturas de ruas, o saneamento, o embelezamento e a modernização do porto deveriam atrair imigrantes e investimentos estrangeiros, além de facilitar a exportação de produtos primários, como o café. As concessões de serviços públicos, como o de transportes urbanos, e a especulação imobiliária favoreciam investidores nacionais e estrangeiros (BENCHIMOL, 1992). Ao mesmo tempo, a repressão da cultura popular, como o carnaval e o comércio de rua, e a intensificação do policiamento dos considerados "vadios", "desempregados" e "perigosos" eram parte dos esforços do Estado para disciplinar a força de trabalho recentemente emancipada (CHALHOUB, 1986). Em segundo lugar, as organizações socialistas cariocas não reivindicavam a extinção do direito de propriedade, mas a melhoria dos salários, condições de trabalho e de vida dos trabalhadores da capital (GOMES, 1994, p. 53). A participação destas organizações na Revolta da Vacina deu-se, em parte, devido ao impacto negativo das reformas no custo de vida e no acesso à moradia perto de oportunidades de trabalho. Portanto, quando os juristas se referiam ao "socialismo" dos reformadores, utilizavam uma concepção idealizada, estrategicamente empregada para defender uma concepção absoluta de propriedade.

Ao invés de um conceito "socialista" de propriedade, coletiva ou administrada pelo Estado, a arquitetura jurídica das reformas urbanas pode ser inserida em um processo de transformação do pensamento jurídico brasileiro que apontava em direção à ideia de que a propriedade possui uma função social. Desde a década de 1870, o conceito de função social e sua variante aplicada à propriedade circulavam no Brasil. Este conceito derivava do positivismo comteano, que transpunha o organicismo biológico para a análise social. Como órgãos de um corpo, instituições sociais, como a propriedade, cumpriam determinadas funçôes. Dentro deste quadro teórico, o uso da propriedade vinha acompanhado de deveres e responsabilidades e, portanto, precisava ser regulado (MALDANER, 2015, p. 30).

Segundo José Reinaldo de Lima Lopes, no final do século XIX e início do $\mathrm{XX}$, um grupo de juristas, com destaque para Clóvis Bevilacqua, Pedro Lessa, Sílvio Romero e Tobias Barreto, liderou uma "virada naturalista" no pensamento 


\section{•• Série Direito, Economia e Sociedade}

jurídico brasileiro. Com base em suas interpretações de autores como o evolucionista Herbert Spencer, estes juristas, participando em um processo de transformação do direito ocidental, se opuseram ao pensamento jurídico clássico, que predominara no mundo durante o século XIX. Eles aplicavam métodos científicos baseados no empiricismo e no experimentalismo das ciências sociais ao direito, rejeitando o conceitualismo e o dedutivismo clássicos. Sua metodologia pregava a substituição de categorias normativas, como "justiça", "direitos" e "obrigaçôes", por categorias empíricas, como "causas", "efeitos" e "funçōes” (LOPES, 2014, p. 44-45).

Os métodos dos "naturalistas" eram receptivos ao determinismo social e biológico e, portanto, compatíveis com projetos de saneamento e segregação urbana. Apesar de adotarem um discurso liberal e de igualdade, alguns juristas foram cúmplices na ideologia da higiene que retratava as classes pobres como perigosas, subscrevendo, em diferentes níveis, à crença na inferioridade racial dos afro-brasileiros e na necessidade de "regenerar" a nação. Estes juristas competiam com os médicos pelo papel de protagonistas no processo regenerador, que, segundo eles, levaria o Brasil ao progresso civilizatório (SCHWARCZ, 1993).

Em 1910, com base em autores como Comte e Spencer, o jurista francês Henri Hayem defendeu, em sua tese de doutorado, que a teoria da propriedade absoluta "havia nascido morta". Para ele, a definição de propriedade do Código Civil francês, de 1804, que inspirara os códigos produzidos na América Latina durante o século XIX, era absoluta apenas em suas intenções. De acordo com Hayem, no Estado moderno, cujo dever era intervir nas relações sociais e econômicas para promover a justiça social, sem, no entanto, adotar "doutrinas socialistas", a propriedade havia se tornado menos individual e mais social (HAYEM, 1910, p. 322439). Hayem foi parte de um diálogo acadêmico que redefiniu o conceito de propriedade na França e teve um impacto profundo no pensamento jurídico latino-americano. Seu maior interlocutor foi Léon Duguit, extensamente lido pelos autores "naturalistas" brasileiros (MIROW, 2010).

Em 1911, Duguit proferiu uma série de palestras, em Buenos Aires, nas quais definiu a propriedade como uma função social. Esta definição encapsulava a interdependência criada pela sociedade urbana e industrial que emergiu durante o século XIX, onde a propriedade não poderia mais ser concebida como um direito abstrato de indivíduos isolados. Tirando conclusões empíricas baseadas em suas observações do direito francês, Duguit argumentou que a propriedade já não era 
mais pensada como um direito subjetivo. A legislação e jurisprudência francesas já aceitavam inúmeras limitações ao uso da propriedade. Por exemplo, quando um proprietário deixava seu edifício em estado de "ruínas", consequentemente falhava na preservação de sua função social, justificando, assim, a intervenção estatal. Obras de infraestrutura, que exigiam inúmeras desapropriações, como a instalação de cabos telegráficos e linhas de eletricidade, também faziam parte do complexo mundo urbano-industrial onde a propriedade já não era mais absoluta (DUGUIT, 1912).

Durante os anos 1920 e 1930, Duguit seria uma das referências mais importantes para o desenvolvimento da noção de função social da propriedade no Brasil. No entanto, a ideia de que a propriedade possuía uma função social apareceu no pensamento jurídico brasileiro mesmo antes de o autor francês tornar sua definição pública, em Buenos Aires. Em 1900, quando o "naturalista” Clóvis Bevilacqua passou a fazer parte dos esforços de codificação, que haviam fracassado desde as tentativas de Teixeira de Freitas, uma noção limitada de propriedade, influenciada pelo direito francês, já ganhava espaço no Brasil. Em seus comentários à versão final do Código Civil, aprovada em 1916, Bevilacqua argumentou que a remoção das referências às limitações impostas ao direito de propriedade, presentes em sua proposta de código de 1900, haviam deixado a definição de propriedade do primeiro Código Civil brasileiro incompleta. Estas limitações estavam presentes dentro do próprio Código, que tinha uma seção sobre desapropriações, e fora dele, nos “impostos e prescriçôes municipais, por motivos de higiene, de utilidade e de aformoseamento" (BEVILACQUA, 1975, p. 1005). Portanto, o conceito de propriedade do Código Civil de 1916 nascera defasado. Historiadores do direito descreveram o conceito do Código como a consolidação da transição do sistema de sesmarias para o sistema de propriedade moderna, operada durante a segunda metade do século XIX (VARELA, 2005, p. 6-8). Porém, de acordo com o próprio jurista encarregado de elaborar o Código, o conceito individual e absoluto de propriedade estaria fora de sintonia com as limitações impostas à propriedade urbana desde o século XIX, que se intensificaram durante as reformas urbanas do início do século XX.

Bevilacqua talvez tenha sido o jurista brasileiro mais influente da Primeira República. Entretanto, foi na obra de Augusto Olympio Viveiros de Castro que as reformas do Rio de Janeiro deixaram sua marca mais profunda. Castro havia se formado, em 1888, na Escola de Direito do Recife, onde os "naturalistas" Romero, Barreto e Bevilacqua lecionaram. Durante sua carreira, Castro foi ministro do Tribunal de Contas (1901), professor da Faculdade Livre de Direito do Rio de Janeiro 
(1907) e ministro do Supremo Tribunal Federal (1915). Castro era um reformista com traços progressistas, que defendia o uso do poder de polícia para a melhoria das condições de vida e trabalho da classe trabalhadora. Ele entendia que a reforma urbana era necessária para remediar os problemas de saneamento da capital e elogiou Pereira Passos por seus "serviços inesquecíveis". Em 1906, enquanto as reformas ainda se desenrolavam, Castro publicou a primeira edição do seu Tratado de sciencia da administração e direito administrativo. Naquela edição, provavelmente escrita antes de ser possível analisar as questões jurídicas levantadas pelas reformas urbanas, Castro pouco escreveu sobre a organização do Distrito Federal e mencionou apenas brevemente as desapropriações do século XIX para a construção de ferrovias (CASTRO, 1906).

No entanto, quatro anos depois, Castro publicou um artigo sobre desapropriações por utilidade pública na Revista de Direito Civil, Commercial e Criminal. Neste artigo, de 1910, ou seja, no mesmo ano que Hayem defendeu sua tese e um ano antes de Duguit falar em Buenos Aires, Castro analisou as questões jurídicas que haviam resultado do uso abrangente das desapropriações para reformar o Rio de Janeiro. Considerando em que medida o novo Estado, baseado em um "dever de sociabilidade", poderia intervir para proteger interesses coletivos e comuns contra o "egoísmo individual", o jurista argumentou que seria absurdo que a propriedade preservasse sua forma mesmo quando se tornasse "um elemento de anti-sociabilidade”. De acordo com ele, a desapropriação era resultado da impossibilidade de harmonizar a "função social" da propriedade com sua "forma individual" em um caso particular (CASTRO, 1910, p. 411).

Castro repetiu esta definição em outro artigo, publicado no ano seguinte, e na edição de 1914 do seu tratado, na qual incluiu um capítulo inteiro dedicado à desapropriação, para discutir as questões jurídicas mais importantes levantadas pelas reformas urbanas da década anterior. Ainda que tenha elogiado Passos, Castro também criticou os excessos do prefeito e as decisões judiciais que os sancionaram. Por exemplo, o autor criticou a decisão da Corte de Apelação, de 1905, que havia autorizado Passos a exigir de um proprietário a demolição parcial de seu edifício, para fins de conformação com as novas regras de alinhamento, sem indenização (CASTRO, 1914, p. 301).

No já mencionado caso de desapropriação da rua Frei Caneca, de 1905, o advogado Pedro Tavares Jr. argumentou que a propriedade deveria ser regulada 
exclusivamente pelo Direito Privado. ${ }^{23}$ Entretanto, o Direito Administrativo havia se tornado fundamental para os debates sobre o melhoramento e saneamento da capital. Como o especialista em Direito Privado Teixeira de Freitas havia colocado, em 1876, a harmonização entre a propriedade e as demandas sociais pertencia à esfera das "Leis de Polícia". No final do século XIX e início do XX, os administrativistas dominavam o debate doutrinário sobre o poder de polícia do Estado. O deslocamento dos debates sobre a propriedade para o Direito Público fazia parte da transformação no direito de propriedade em curso. Este deslocamento indicava que a propriedade era cada vez mais pensada não apenas como um direito subjetivo, pertencente à esfera privada individual, mas também como um bem social, que deveria ser regulado pelo Estado para a preservação de interesses coletivos, como a higiene e o desenvolvimento econômico.

O conceito de propriedade que Castro usou para justificar as desapropriações no Rio de Janeiro talvez tenha sido uma definição transicional. De acordo com o jurista, a propriedade tinha uma dimensão dupla, social e individual. A definição de Duguit, de 1911, era mais radical porque excluía o papel da propriedade como direito individual; a propriedade não tem, mas é uma função social. Entre outras referências, a teoria de Duguit faria parte da redefinição do conceito de propriedade operada nos anos 1920 e 1930, no Brasil. O próprio Duguit fora, provavelmente, influenciado pela doutrina social da Igreja Católica. Esta doutrina se baseava na encíclica papal Rerum Novarum, de 1891, conhecida por sua contribuição para a história intelectual dos direitos dos trabalhadores. A encíclica rejeitava o comunismo e o socialismo e clamava os trabalhadores a não aderir a protestos e conspirações. Apesar de definir a propriedade como um direito inviolável, condição da ordem social, a encíclica indicava que a propriedade deveria ser "considerada em relação às obrigaçôes sociais e domésticas do homem” (MIROW, 2016, p. 194).

Além da teoria de Duguit e da doutrina social da Igreja, o direito de propriedade brasileiro foi influenciado pelas constituições do México, de 1917, e de Weimar, de 1919, que introduziram concepçôes limitadas de propriedade no vocabulário do constitucionalismo mundial. Nos anos 1930, no contexto de emergência e consolidação de um Estado anti-liberal no Brasil, a função social da propriedade ganhou uma conotação mais dinâmica, que abria espaço para transformações so-

23 Arquivo Nacional, Fundo: Juízo dos Feitos da Fazenda Municipal -o3Y, João Leopoldo Modesto Leal, 1905, 54, caixa 619. 


\section{•• Série Direito, Economia e Sociedade}

ciais, substituindo a noção comteana, do século XIX, que apresentava as funções como papéis estáticos em uma sociedade orgânica. Ainda que os deputados constituintes tenham, eventualmente, removido a expressão "função social da propriedade" do texto final, a Constituição de 1934 determinou que o direito de propriedade não poderia ser exercido "contra o interesse social ou coletivo" (MALDANER, 2015, p. 73)..$^{24}$

Poucos anos depois que as autoridades federais e municipais uniram forças para implementar um plano de reformas que expulsou milhares de pessoas do centro do Rio de Janeiro, Viveiros de Castro justificou estas medidas com base na função social da propriedade. Assim como outros conceitos, como os de interesse, necessidade e bem público, a função social da propriedade podia servir aos interesses de administradores reformistas, que defendiam um processo de modernização excludente para a cidade e para a nação. Mesmo que o conceito não tenha feito parte da arquitetura jurídica que permitiu as reformas, a expansão do poder executivo e as crescentes limitaçôes impostas ao direito de propriedade levaram Castro a publicar sua definição pioneira, em 1910. Ironicamente, durante o século XX, os residentes dos morros cariocas, que se multiplicaram durante as reformas urbanas, invocariam a função social da propriedade, um conceito que havia sido usado para justificar a segregação urbana, para reivindicar seu direito de permanecer na cidade.

\section{A INVIOLABILIDADE DO LAR}

A história da resistência dos pobres ao plano de reformas da capital, no início do século XX, não é uma história sobre a propriedade. Antes da expansão das favelas e dos subúrbios, os trabalhadores do Rio de Janeiro moravam nos cortiços, estalagens e outras formas de habitação coletiva, no centro da cidade. Desde meados do século XIX, um crescente número de libertos e imigrantes ocupara estes prédios velhos, superlotados e anti-higiênicos, divididos em pequenas unidades, pelas quais os proprietários e arrendatários cobravam preços absurdos. Sem contratos de aluguel ou qualquer proteção legislativa, os inquilinos viviam sob constante ameaça de despejo. Ainda que as autoridades reconhecessem a necessidade de construir moradia para os pobres, o que foi de fato construído serviu, sobretudo, aos interesses das empreiteiras e dos especuladores, que lucravam com a demolição dos cortiços. As vilas operárias construídas por Pereira Passos na Avenida Salvador de Sá, em 1906,

24 Constituição da República dos Estados Unidos do Brasil, de 16 de julho de 1934, art. 113, $₫ 17$. 
por exemplo, eram suficientes para abrigar apenas 10\% da população despejada e removida de suas residências pela reforma urbana (CARVALHO, 1995, p. 147-169).

De um lado, os reformadores, representados nos tribunais pelos procuradores $\mathrm{da}$ saúde pública, ordenavam o fechamento e despejo dos cortiços com base na proteção da saúde dos pobres contra a exploração gananciosa dos proprietários. Porém, silenciavam a respeito da falta de alternativas para os despejados. De outro, os proprietários invocavam o direito de propriedade individual e absoluto. Como vimos na seção anterior, esta classe, às vezes representada por associações, defendeu seus interesses empregando diversas estratégias, como a articulação política, a litigância e a mobilização da opinião pública através dos jornais. Os inquilinos, no entanto, não podiam reivindicar direitos de propriedade sobre os pequenos quartos onde moravam. Em algumas ocasiōes, afirmavam justamente o contrário, a fim de evitar multas e prisões. Quando os agentes sanitários processavam inquilinos pelas más condições de higiene dos prédios onde moravam, era comum que os moradores argumentassem que não podiam ser responsabilizados, justamente por não serem proprietários.

Entretanto, as multas e prisões eram apenas parte do esforço disciplinador baseado no "Código de Torturas". O Código de 1904 também autorizava os agentes a realizar expurgos domiciliares, contra o mosquito transmissor da febre amarela, e ordenar o fechamento dos prédios, quando entendiam que a situação era irremediável. Tudo isso podia ser e foi feito com a ajuda da polícia, nos moldes da "invasão militar" que havia demolido o famigerado cortiço Cabeça de Porco, em 1893. Contra estas medidas sanitárias violentas, os trabalhadores do Rio de Janeiro desenvolveram uma consciência de direitos baseada na inviolabilidade de domicílio. Desde o início do século XIX, especialmente quando entrou em vigor a Constituição do Império, de 1824, os liberais brasileiros haviam modernizado o conceito de "casa". O conceito que protegia, desde os tempos coloniais, o poder privado dos senhores e patriarcas sobre seus escravos, mulheres e filhos, foi traduzido como um direito constitucional (SEELAENDER, 2017). Esta tradução modernizou as estruturas de dominação patriarcal e racial que continuaram a definir a sociedade brasileira, mesmo após a abolição, em 1888, e a proclamação da república, em 1889. Tanto a Constituição de 1824, quanto a Constituição Republicana, de 1891, protegiam a casa como um "asilo inviolável" dos indivíduos. ${ }^{25}$ Comentando a pri-

25 Constituição Política do Império do Brazil, de 15 de março de 1824, art. 179, VII; Constituição da República dos Estados Unidos do Brasil, de 24 de fevereiro de 1891, art. 72, $\$ 11$. 


\section{•• Série Direito, Economia e Sociedade}

meira constituição, Pimenta Bueno argumentou que a casa era o "asilo da família, do seu sossego, de sua honestidade" (BUENO, 1857, p. 414). Após 1889, referências ao direito anglo-saxão proliferaram, associando esta proteção constitucional ao princípio inglês my house is my castle e à Quarta Emenda da Constituição dos Estados Unidos (BARBALHO, 1924, p. 428).

O conceito de "casa", "lar" ou "domicílio" foi determinante na mobilização para a Revolta da Vacina, de 1904. Políticos de oposição, como Lauro Sodré - do grupo positivista que havia perdido espaço para as oligarquias rurais -, e líderes operários, como os do Centro das Classes Operárias, articularam a defesa do lar como direito constitucional e valor tradicional, protetivo da estrutura patriarcal familiar, contra a vacinação e outros tipos de intervenção estatal, como os expurgos domiciliares. Esta mobilização, que os positivistas usariam como oportunidade para uma tentativa fracassada de golpe de estado, ocorreu nos jornais e nas reuniōes do Largo do São Francisco. ${ }^{26}$ Nos tribunais, advogados já haviam usado a proteção constitucional à inviolabilidade de domićlio como argumento contra o Código Sanitário, mas ainda sem sucesso. ${ }^{27}$ Porém, a revolta, que deixou um número incerto de mortos, feridos e barricadas pela cidade, mudaria o rumo da resistência no judiciário.

Em janeiro de 1905, enquanto as tropas do governo ainda perseguiam os supostos conspiradores e participantes na revolta, o caso do comerciante português Manuel Fortunato Costa chegou ao Supremo Tribunal Federal. Como parte de uma agressiva campanha de saneamento no bairro do Rio Comprido, os agentes sanitários haviam notificado Costa de que sua casa seria alvo de um expurgo. Costa, no entanto, recorreu ao Supremo Tribunal Federal (STF), pedindo um habeas corpus contra o expurgo, com o auxílio de seu amigo e advogado, Pedro Tavares Jr., o mesmo que defendeu os proprietários da rua Frei Caneca. Enquanto o caso ainda estava pendente, um "exército" de mata-mosquitos, agentes sanitários e policiais invadiu a casa do comerciante e realizou o procedimento. Assim como em outras ocasiōes, a justiça não fora célere o suficiente para conter o ímpeto dos reformadores. No entanto, após o fato, o STF declarou inconstitucionais os expurgos baseados no Código Sanitário. De acordo com a corte, a Constituição de 1891 permitia

\footnotetext{
26 A mobilização contra o empoderamento dos serviços de higiene começou aproximadamente um ano antes, em dezembro de 1903. Defesa do lar, Jornal do Brasil, 2 de dezembro de 1903.

27 Regulamento Sanitário. Habeas Corpus, Jornal do Brasil, 17 de maio de 1904.
} 
exceções à inviolabilidade de domicílio apenas quando estas fossem criadas pelo legislador. Como se tratava de um decreto do executivo, ainda que o Congresso tivesse previamente delegado seus poderes ao Presidente, o Código Sanitário não poderia ter criado tal exceção. ${ }^{28}$

Costa não fazia parte da classe de inquilinos despossuídos. Entretanto, a decisão do STF deu nova vida às lutas dos trabalhadores contra o que os positivistas chamavam de "despotismo sanitário". Logo após a decisão, os jornais noticiaram uma "chuva" de habeas corpus, que, segundo parte da imprensa, poderia inviabilizar a reforma sanitária. Jornais alinhados com o plano do governo defendiam o "direito da coletividade" contra a "onda avassaladora do direito individual", invocando o argumento reformador que condicionava o exercício de direitos individuais, como a inviolabilidade de domicílio e a propriedade, ao bem comum ou social, entendido como o saneamento e embelezamento da cidade. ${ }^{29}$

Algumas semanas após a decisão do caso de Costa, Augusto Queirós, membro da União Operária do Engenho de Dentro, composta predominantemente por trabalhadores da Estrada de Ferro Central do Brasil, entrou com um pedido de habeas corpus coletivo "em favor das oprimidas classes operárias e proletárias" do Rio de Janeiro. Segundo Queirós, após a concessão do habeas corpus a um "abastado capitalista", alguém deveria vir em socorro dos mais pobres contra as violências da Diretoria Geral de Saúde Pública. O peticionário, que assinou apenas como "cidadão", argumentou que sua petição - baseada na inviolabilidade do lar - abriria espaço para que os ministros do STF fizessem "curvar o Operariado perante [suas] togas”. Porém, ainda que Queirós tenha reproduzido exatamente o argumento vencedor no caso de Costa, o STF recusou-se a dar prosseguimento ao pedido. Assim como outros pedidos de habeas corpus coletivo, o de Queirós tinha vícios formais, como a ausência de um "paciente" determinado. ${ }^{30}$ Houve também pedidos individuais de habeas corpus. No mesmo ano de 1905, por exemplo, o "Africano" João da Rocha apelou para o STF contra uma multa por infração sanitária que poderia levar a sua prisão, usando o argumento baseado na

28 Arquivo Nacional, Fundo: Supremo Tribunal Federal, Série: Habeas Corpus, 1905, Cód. Ref. BV.0.HCO.2046.

29 A nova doutrina, O Paiz, 14 de fevereiro de 1905.

30 Arquivo Nacional, Fundo: Supremo Tribunal Federal, Série: Habeas Corpus, 1905, Cód. Ref. BV.0.HCO.2293. 


\section{•• Série Direito, Economia e Sociedade}

inviolabilidade de domicílio. ${ }^{31}$ Estes casos mostram que, ainda que o plano de saneamento tenha avançado, os trabalhadores da cidade foram capazes de articular sua consciência de direitos em mobilização jurídica contra o que entendiam serem atos estatais violentos e ilegítimos.

\section{DA CASA À PROPRIEDADE}

Minha hipótese, que ainda deve ser testada em pesquisas futuras, é de que as pessoas removidas do centro do Rio de Janeiro levaram consigo a consciência de direitos e a experiência de mobilização contra as reformas do início do século XX para as comunidades que estabeleceram nos morros e subúrbios da cidade. Os historiadores Eneida Queiroz e Romulo Costa Mattos confirmam que, já durante e pouco após as reformas, moradores de favelas acionaram advogados e foram à justiça reivindicar seus direitos (QUEIROZ, 2008). Em 1911, por exemplo, uma comissão de moradores do Morro de Santo Antonio contatou Evaristo de Moraes, advogado militante, conhecido por defender prostitutas e sindicatos, para mobilizar o judiciário contra uma ordem de despejos da Diretoria Geral de Saúde Pública. Porém, apesar de ter se mostrado otimista alguns meses antes, Moraes concluiu que seria incapaz de ajudar os moradores de maneira significativa (MATTOS, 2013).

De acordo com Brodwyn Fischer, durante a Era Vargas (1930-1954), os moradores das favelas cariocas resistiram às tentativas de remoção promovidas por agentes privados, recorrendo a alianças com políticos populistas e aos tribunais. Naquele momento, o conceito de "casa” já não era central para as lutas pelo direito à cidade. Os moradores invocavam narrativas que apresentavam suas comunidades como ocupações de espaços vazios, articulando história e direito em argumentos baseados na usucapião. Ao mesmo tempo, ainda que de maneira tímida, os defensores dos direitos destes moradores apelavam para o conceito de interesse social, que limitava o direito de propriedade, nos termos das constituições de 1934 e 1946 (FISCHER, 2008).

Apesar de ter sido usada, no início do século XX, para justificar um plano de reformas que segregou a capital, a função social da propriedade se tornou, ao final do século, um conceito fundamental para as lutas pelo direito à moradia nas cidades brasileiras. Esta proeminência da função social da propriedade deveu-se, entre outros fatores, a como os movimentos sociais e a doutrina jurídica interpretaram o texto da Constituição de 1988. No entanto, apenas a partir de novas pesquisas nos

31 Arquivo Nacional, Fundo: Supremo Tribunal Federal, Cód. Ref. BV.0.HCO.2955. 
arquivos judiciários poderemos reconstruir a história recente das mobilizações jurídicas dos herdeiros do processo de segregação iniciado na primeira década do século XX.

\section{CONCLUSÃO}

Este artigo apresentou histórias que, apesar de tradicionalmente separadas por fronteiras historiográficas, devem ser contadas conjuntamente: uma história "de cima”, focada no papel das políticas públicas e da doutrina jurídica no processo de construção do Estado-nação brasileiro, e uma história "de baixo", que resgata o papel dos movimentos sociais e da mobilização jurídica neste processo. Em resumo, as crescentes limitaçôes impostas ao direito de propriedade urbana durante o século XIX, que culminaram com o plano reformador do início do século XX, contribuíram para o desenvolvimento doutrinário do conceito de função social da propriedade. Ironicamente, este conceito, que foi usado para justificar um plano reformador que segregou a cidade, seria, no decorrer do século XX, invocado nas lutas sociais por acesso à cidade. Apresentei os termos desta transição na forma de uma hipótese: os despejados dos cortiços, que fundaram as comunidades cariocas, levaram consigo a consciência de direitos e as estratégias de mobilização jurídica desenvolvidas durante as reformas urbanas, mas a base conceitual da resistência às remoçôes mudou do conceito de casa, ou domicílio, para ideias relacionadas à propriedade, como a usucapião e a função social. Se esta hipótese se confirmar, podemos dizer que a remoção dos pobres do centro da cidade criou laços ainda mais fortes, forjados em narrativas baseadas no direito de propriedade, entre os despossuídos e a cidade do Rio de Janeiro.

\section{REFERÊNCIAS}

\section{Arquivos consultados}

Acervo Judiciário, Arquivo Nacional

Hemeroteca Digital, Biblioteca Nacional (online)

Mensagens do Prefeito ao Conselho Municipal, Arquivo Nacional

Portal de Legislação, Câmara dos Deputados (online)

\section{Fontes primárias impressas}

BARBALHO, João. Constituição Federal Brasileira: commentarios. Rio de Janeiro: F. Briguiet e Cia. Editores, 1924. 
•• Série Direito, Economia e Sociedade

BEVILACQUA, Clóvis. Código Civil dos Estados Unidos do Brasil comentado. Rio de Janeiro: Editora Rio, 1975)

BUENO, José Antonio, Direito publico brazileiro e analyse da Constituição do Imperio. Rio de Janeiro: Typographia Imp. e Const. de J. Villeneuve \& C., 1857.

CASTRO Augusto Olympio Viveiros de. Desapropriação por utilidade pública, segundo a doutrina e a legislação brasileira. Revista de Direito Civil, Commercial e Criminal, v. XVIII, 1910.

CASTRO Augusto Olympio Viveiros de. Tratado de sciencia da administração e direito administrativo. Rio de Janeiro: Imprensa Nacional, 1906.

CASTRO Augusto Olympio Viveiros de. Tratado de sciencia da administração e direito administrativo. Rio de Janeiro: Jacintho Ribeiro dos Santos, 1914.

DUGUIT, Léon. Les transformations générales du droit privé depuis le Code Napoléon. Paris: Librairie Félix Alcan, 1912.

FREITAS, Augusto Teixeira de. Consolidação das Leis Civis. Rio de Janeiro: B. L. Garnier, 1876.

HAYEM, Henri. Essai sur le droit de proprieté et ses limites. Paris: Arthur Rousseau, 1910.

O DIREITO. Revista Mensal de Legislação, Doutrina e Jurisprudência, v. 107, set.-dez. 1908.

\section{Fontes Secundárias}

BENCHIMOL, Jaime L. Pereira Passos: um Haussman tropical: A renovação urbana da cidade do Rio de Janeiro no início do século XX. Rio de Janeiro: Secretaria Municipal de Cultura, Turismo e Esportes, Departamento Geral de Documentação e Informação Cultural, Divisão de Editoração, 1992.

CANTISANO. Direito, propriedade e reformas urbanas: Rio de Janeiro, 1903-1906. Estudos Históricos 29, 58, 2016: 401-420.

CANTISANO. Lares, tribunais e ruas: a inviolabilidade de domicílio e a revolta da vacina. Direito \& Praxis 6, 11, 2015: 294-325.

CARVALHO, José Murilo de. Os bestializados: O Rio de Janeiro e a República que não foi. São Paulo: Companhia das Letras, 2011.

CARVALHO, Lia de Aquino. Habitaçôes populares: Rio de Janeiro, 1866-1906. Rio de Janeiro: Prefeitura da Cidade do Rio de Janeiro, 1995.

CARVAlHO, Marieta Pinheiro de. Uma ideia ilustrada de cidade: as transformações urbanas no Rio de Janeiro de D. João VI (1808-1821). Rio de Janeiro: Odisséia, 2008.

CHALHOUB, Sidney. Cidade febril: cortiços e epidemias na corte imperial. São Paulo: Cia das Letras, 1996.

CHALHOUB, Sidney. Trabalho, lar e botequim: o cotidiano dos trabalhadores no Rio de Janeiro na Belle Époque. São Paulo: Brasiliense, 1986. 
FISCHER, Brodwyn. A poverty of rights: citizenship and inequality in twentieth-century Rio de Janeiro. Palo Alto: Stanford, 2008.

FURTADO, Janaína Lacerda. Os dois lados da moeda: a comissão de melhoramentos da cidade do Rio de Janeiro e o discurso de higiene e saneamento no século XIX Dissertação (Mestrado) - Universidade do Estado do Rio de Janeiro, 2003.

GOMES, Angela Maria de Castro. A invenção do trabalhismo. Rio de Janeiro: RelumeDumará, 1994.

GRINBERG, Keila. O fiador dos brasileiros: cidadania, escravidão e direito civil no tempo de Antonio Pereira Rebouças. Rio de Janeiro: Civilização Brasileira, 2002.

LOPES, José Reinaldo de Lima. Naturalismo jurídico no pensamento brasileiro. São Paulo: Saraiva, 2014.

MALDANER, Alisson Thiago, De expressão a conceito: função social e função social da propriedade no Brasil de 1870 a 1934. Dissertação (Mestrado) - UFRRJ, 2015.

MAMIGONIAN, Beatriz Gallotti. O Estado nacional e a instabilidade da propriedade escrava: a Lei de 1831 e a matrícula dos escravos de 1872. Almanack Guarulhos, 2, 2011, 20-37.

MATTOS, Romulo Costa. Shantytown Dweller' Resistance in Brazil's First Republic (1890-1930): Fighting for the Right of the Poor to Reside in the City of Rio de Janeiro. International Labor and Working-Class History, 83 (Spring 2013): 54-69.

MEADE, Teresa A. Civilizing Rio: reform and resistance in a Brazilian city, 1889-1930. University Park: The Pennsylvania State University, 1999.

MIROW, Matthew C. The social-obligation norm of property: Duguit, Hayem, and others, 22 Florida Journal of International Law 191, 2010.

MIROW, Matthew C. Rerum Novarum: new things and recent paradigms of property law, 47. The University of the Pacific Law Review, 183, 2016.

MOTA, Márcia M. M. Nas fronteiras do poder. Conflito e direito à terra no Brasil do século XIX. Rio de Janeiro: Arquivo Público do Estado do Rio de Janeiro, 1998.

QUEIROZ, Eneida Quadros, Justiça Sanitária - Cidadãos e Judiciário nas Reformas Urbana e Sanitária - Rio de Janeiro (1904-1914). Dissertação (Mestrado) - Universidade Federal Fluminense, 2008.

SCHULTZ, Kristen. Tropical versailles: Empire, Monarchy, and the Portuguese Royal Court in Rio de Janeiro, 1808-1821. New York/London: Routledge, 2001.

SCHWARCZ, Lilia Moritz. O espetáculo das raças: cientistas, instituições e questão racial no Brasil, 1870-1930. São Paulo: Cia das Letras, 1993.

SEELAENDER, Airton Cerqueira Leite. A longa sombra da casa. Poder doméstico, conceitos tradicionais e imaginário jurídico na transição brasileira do antigo regime à modernidade. Revista do Instituto Histórico e Geográfico Brasileiro, 178, 473, 2017: 327-424. 
-• Série Direito, Economia e Sociedade

SEELAENDER, Airton Cerqueira Leite. A "polícia” e as funções do estado - notas sobre a "polícia" no antigo regime. Revista da Faculdade de Direito - UFPR, 47, 2008.

VARELA, Laura Beck, Das sesmarias à propriedade moderna: um estudo de história do direito brasileiro. Rio de Janeiro: Renovar, 2005. 